\title{
Isolation and identification of Yersinia enterocolitica in bovine milk samples of bulk tanks from dairy farms in São Paulo, Brazil
}

\section{Isolamento e identificação de Yersinia enterocolitica em amostras de leite cru bovino a partir de tanques de expansão, São Paulo, Brasil}

\author{
Amanda Bezerra Bertolini1 ${ }^{*}$; Marcelo Augusto Orsi Dutra ${ }^{1}$; Lívia Maísa Guiraldi²; \\ Wesley José dos Santos²; Maria Izabel Merino de Medeiros ${ }^{3}$; Simone Baldini \\ Lucheis $^{3}$
}

\begin{abstract}
Milk and its derivatives are good substrates for the proliferation of pathogenic and quality-deteriorating microorganisms, demanding rigorous care with milking, processing, and storage. Among the various bacteria that can grow in raw refrigerated milk, Yersinia enterocolitica, is an invasive enteropathogen of humans. This bacterium can cause a number of intestinal and extraintestinal clinical symptoms, ranging from mild gastroenteritis to mesenteric lymphadenitis, similar to appendicitis. To evaluate the prevalence of pathogenic Yersinia enterocolitica in raw milk from bulk milk tanks located in the State of São Paulo, 102 bovine milk samples (one per dairy farm) were evaluated by microbiological analyses, followed by biochemical tests PCR and genetic sequencing. Microbiological testing did not isolate $Y$. enterocolitica. However, PCR analysis revealed six samples that were positive for $Y$. enterocolitica (5.9\%), confirmed by genetic sequencing. Only the inv gene was detected, which is present in virulent and avirulent $Y$. enterocolitica strains. There was great difficulty in microbiological isolation due to the difficulty of competitiveness of $Y$. enterocolitica in a very rich microbiota of raw milk. Although virulence genes known to be present in potentially pathogenic strains of $Y$. enterocolitica have not been identified, the presence of this pathogen in milk from expansion tanks, identified through PCR and confirmed by genetic sequencing, suggests that $Y$. enterocolitica may be a risk to public health, especially if milk and its derivatives are consumed without heat treatment.
\end{abstract}

Key words: Microbiological analyses. Molecular diagnosis. Bovine milk. Public health. Yersiniosis.

\section{Resumo}

O leite e seus derivados possuem substratos que favorecem o desenvolvimento de micro-organismos patogênicos e deteriorantes, devido a isso, cuidados rigorosos são exigindo durante a ordenha, processamento e seu armazenamento. Dentre os vários grupos de bactérias que podem contaminar o leite refrigerado cru está Yersinia enterocolitica. Esta bactéria pode causar a uma série de sintomas clínicos intestinais e extraintestinais, variando de gastroenterite leve a linfadenite mesentérica, semelhante à apendicite. Para avaliar a prevalência de $Y$. enterocolitica patogênica no leite cru de

1 Discentes, Curso de Mestrado, Programa de Pós-Graduação em Medicina Veterinária, Universidade Estadual Paulista Júlio de Mesquita Filho, UNESP, Botucatu, SP, Brasil. E-mail: amanda-bezerra@hotmail.com; dutramo@hotmail.com

2 Discentes, Curso de Doutorado, Programa de Pós-graduação em Doença Tropical, UNESP, Botucatu, SP, Brasil. E-mail: livia_ maisa_g@hotmail.com; wesleysantos@fc.unesp.br

3 Pesquisadoras Dras, Agência Paulista de Tecnologia dos Agronegócios, APTA, Bauru, SP, Brasil. E-mail: belvt@uol.com.br; silucheis@apta.sp.gov.br

* Author for correspondence 
tanques de expansão localizados no estado de São Paulo, foram avaliadas 102 amostras de leite bovino, por análises microbiológicas, seguido de provas bioquímicas; a Reação em Cadeia de Polimerase (PCR) e sequenciamento genético. Não houve o isolamento de $Y$. enterocolitica pelas provas microbiológicas clássicas. No entanto, a análise de PCR, realizada diretamente do leite, revelou seis (6) amostras positivas para Y. enterocolitica (5,9\%), confirmadas por sequenciamento genético. Somente o gene inv, foi detectado, que pode estar presente em cepas virulentas e avirulentas. Houve dificuldade de isolamento microbiológico devido à dificuldade de competitividade da $Y$. enterocolitica em uma microbiota muito rica do leite cru. Ainda que não tenham sido identificados os genes de virulência que sabidamente estão presentes em cepas de $Y$. enterocolitica potencialmente patogênicas, a presença desse patógeno no leite dos tanques de expansão, identificadas através da PCR e confirmadas por sequenciamento genético, sugere que Yersinia enterocolitica pode ser um risco potencial para a saúde pública, principalmente se o leite e seus derivados forem consumidos sem tratamento térmico.

Palavras-chave: Análise microbiológica. Diagnóstico molecular. Leite bovino. Saúde pública. Yersiniose.

\section{Introduction}

The increase in the demand for unpasteurized milk has emphasized the importance of hygienic and microbiological quality of raw milk (RUUSUNEN et al., 2013). Even though this practice is illegal in Brazil(BRASIL, 2017), the sale of this type of milk is carried out openly throughout the State of São Paulo. The increase in raw milk consumption is justified by the taste, convenience, cost, and high nutritional value (KAYLEGIAN et al., 2008); however, milk is an ideal medium for the multiplication of a wide variety of pathogenic bacteria, and acts as an important substrate for transporting microorganisms from infected animals to humans. Despite being produced by healthy animals, contamination of milk can occur during milking, from contaminated water, milking equipment, and from the hands of milkers (TAVARES et al., 2017).

Psychrotrophic bacteria develop at low temperatures, representing one of the main groups of pathogens and degrading agents present in refrigerated raw milk and its derivatives. Yersinia enterocolitica ( $Y$. enterocolitica) is one of the pathogenic psychrotrophic bacteria that may be present in milk, posing a high risk to consumers due to the consumption of raw or inadequately pasteurized milk, and leading to outbreaks of enteric infections (SOLTAN-DALLAL et al., 2004).

$Y$. enterocolitica is an invasive enteropathogen that causes a series of intestinal clinical symptoms, with diarrhea being the most common (SILVA JUNIOR, 2014) and extraintestinal clinical symptom, ranging from mild gastroenteritis to mesenteric lymphadenitis and acute abdominal pain, which mimics appendicitis, and in rare cases, may progress to septicemia.

$Y$. enterocolitica is transmitted to humans almost exclusively by the ingestion of contaminated food and water (FALCÃO et al., 2006). The pathogen has already been isolated from raw milk and its derivatives on ice used for human consumption, pork and its derivatives, poultry meat, as well as fecal material from humans and sick animals and from the environment (VIDON; DELMAS, 1981; FALCÃO et al., 2002; DALLAL et al., 2004; PINTO et al., 2006; FALCÃO et al., 2006; ARCURI et al., 2008; HANIFIAN; KHANI, 2012; RUUSUNEN et al., 2013; DARWISH et al., 2015). In Brazil, $Y$. enterocolitica was isolated from several foods, mainly in the states of São Paulo, Rio de Janeiro, and Rio Grande do Sul (PINTO et al., 2006; TAVARES et al., 2017). In 2007, 8792 cases of yersiniosis were reported in humans in the European Union, making $Y$. enterocolitica the third most isolated zoonotic agent in human enteritis, behind only Salmonella and Campylobacter (DARWISH et al., 2015). However, in Brazil, $Y$. enterocolitica infections are not reported as frequently as in several other countries, maybe because this fact is attributed to the low occurrence of the microorganism in Brazil or due to the non- 
utilization of optimal isolation techniques and characterization of this bacterium (FALCÃO et al., 2006).

Considering the prevalence of the consumption of raw milk and its derivatives, errors in thermal processing in the industry, the underdiagnosis of this pathogen due to the use of inadequate techniques for its identification, and the small number of studies conducted in Brazil, we proposed the research and identification of $Y$. enterocolitica in milk samples from bulk tank milk of different dairy farms. There is a significant lack of studies related to this bacterium, which is of great importance to public health.

\section{Materials and Methods}

Microbiological analyses and biochemical and molecular identification were performed at the Animal Sanity Laboratory of Bauru (LASAB) of APTA / SAA - Paulista Agency of Agribusiness Technology - Bauru, SP, Brazil.

One hundred and two (102) milk samples were collected directly from the individual expansion tanks in 102 dairy farms in São Paulo (one sample per farm). For the sample calculus, a prevalence of $7 \%$ of pathogens identification was assumed (RUUSUNEN et al., 2013; DARWISH et al., 2015), with a margin of error of 5\%. Such calculus was possible by using the OpenEpi program (DEAN et al., 2015).

The milk samples were collected from tanks at a maximum temperature of $4^{\circ} \mathrm{C}$. Milking had been carried out a maximum of 48 hours prior. Previously sterilized stainless steel shells were used to collect a volume of $100 \mathrm{~mL}$ for each sample in sterile flasks. They were kept in cooler boxes with ice and finally taken to the lab.

A volume of $25 \mathrm{~mL}$ of each milk sample was added to $225 \mathrm{~mL}$ of buffered peptone water $\mathrm{pH}$ 7.2, which was the pre-enrichment phase, and held for 30 days at $4{ }^{\circ} \mathrm{C}$ refrigeration. After 30 days, $1 \mathrm{~mL}$ of the pre-enrichment solution was added to $100 \mathrm{~mL}$ of Peptone Sucrose Tris Sodium Azide Ampicillin (PSTA) and incubated at $28^{\circ} \mathrm{C}$ for 48 hours, which was the enrichment phase. (VIDON; DELMAS, 1981).

After incubation of the material, $1 \mathrm{ml}$ of the PSTA-enriched broth was used for inoculation in three different culture media, which were chosen for being the most used ones for isolation of Yersinia enterocolitica: MacConkey agar (TRABULSI; ALTERTHUM, 2015), Yersinia selective agar (WAUTERS et al., 1987) and Hektoen agar with $5 \mathrm{mg} / \mathrm{L}$ ampicillin (VIDON; DELMAS, 1981). All plates were incubated at $28^{\circ} \mathrm{C}$ for 48 hours. All suspect colonies were submitted to Gram staining, oxidase and catalase tests, and the API 20E bioquimical identification system (BioMerieux) incubated at $28^{\circ} \mathrm{C}$ (TRABULSI; ALTERTHUM, 2015). A reference strain of Yersinia enterocolitica was used as a positive control for each Yersinia biochemical test of the serological group 1B, 2, 3, 4 and 5 (FIOCRUZ reference CLIST: 3438, 3439, 3440, 3442 and 3443), Department of Bacteriology, IOC / FIOCRUZ (Rio de Janeiro, RJ).

Colonies were frozen in a $20 \%$ glycerol solution and then DNA was extracted for the molecular tests.

In order to evaluate the competitiveness of the studied bacteria, two dilutions of Yersinia enterocolitica (strain 5B, reference FIOCRUZ CLIST 3443) were added to two of raw milk samples, one on scale 1 (approximately $3.0 \mathrm{x}$ $10^{8}$ ) and one on scale 5 (approximately $1.5 \times 10^{9}$ ) according to the McFarland scale (BIER, 1984). After the contamination, the pre-enrichment was carried out in peptone water for 30 days, followed by enrichment in PSTA at $28^{\circ} \mathrm{C}$ for 48 hours and seeding in Yersinia agar incubated at $28^{\circ} \mathrm{C}$ for 48 hours.

The conventional PCR technique was performed from tank milk samples and from the suspected $Y$. enterocolitica colonies isolated from the different culture media described above. 
DNA extraction was performed with the Illustra Blood GenomicPrep Mini Spin Kit (GE Healthcare), with modifications when carried out directly from raw milk samples (MARTINS et al., 2015), and according to the manufacturer when carried out from cryopreserved colonized. After the extraction, all the milk samples were submitted to PCR testing for the detection of all species of the genus Yersinia, using the primers 227Fmod and 669R, which produced 428 to $465 \mathrm{bp}$ fragments (STENKOVA et al., 2008).

All milk samples were also submitted to the PCR assay for Y. enterocolitica detection, using 16S rRNA F and 16S rRNA R primers, which produced 325 bp fragments (BALAKRISHNA et al., 2012). PCR was also performed for the virulence genes of pathogenic species of $Y$. enterocolitica, namely: inv gene, primers YC1F and YC2R (RASMUSSEN et al., 1994); ail gene, primers ailF and ailR; yada gene, primers YadAF and Yadar; virf gene, primers $\operatorname{virF} / \mathrm{lcr} \mathrm{F}$ and virF/lcrR; ystA gene, primers ystAF and ystAR; and $y s t B$ gene, primers ystBF and ystBR (THOERNER et al., 2003). Sequencing was carried out in a commercial laboratory located in Botucatu, São Paulo, Brazil. After the sequencing, electropherograms were analyzed using the EMBOSS/Merger, Chromas Lite, and Geneious 4.8.3 programs to obtain a consensus sequence. In all PCRs and sequencing, negative controls (ultrapure autoclaved water) and positive controls were used. The positive control was a $Y$. enterocolitica DNA from line 8081 (NCTC13174) which had the virulence genes screened, courtesy of the National Reference Center Collection in Yersinia spp, except Yersinia petis (University of Pharmaceutical Sciences of Ribeirão Preto, USP, $\mathrm{SP})$

\section{Results}

There was no isolation of $Y$. enterocolitica in the microbiological analysis. In all seeded plates, except for the negative control, exuberant isolation of several colonies, mostly mucoid, was observed, including on Yersinia agar, which was expected to be a selective agar for the studied bacterium.

In total, 356 different colonies were isolated; only $89(25 \%)$ isolates were candidates for $Y$. enterocolitica, that is, small, rounded colonies measuring no more than $1 \mathrm{~mm}$ in diameter on MacConkey agar, reddish colonies on Yersinia agar or of orange color on Hektoen agar. After the biochemical tests, none of the colonies were identified as $Y$. enterocolitica. One of the samples was positive for Shigella sonnei, a pathogenic bacterium of great importance for public health.

Regarding the competitiveness test, it was observed that even after the contamination of the raw milk with high concentrations of Yersinia enterocolitica (approximately $3.0 \times 10^{8}$ and approximately $1.5 \times 10^{9}$ ), the re-isolation was not possible due to the exuberant growth of other contaminating bacteria.

PCR performed on the 89 colonies suggestive of Yersinia enterocolitica; which were all negative, confirming the findings of the microbiological analysis.

On the other hand, when the DNA extraction was carried out directly from the raw milk samples, the PCR's identified six samples $(5,9 \%)$ as suggestive of Yersinia enterocolitica. Subsequently, amplified PCR products were submitted to Sanger sequencing, presenting $98 \%, 99 \%$ and $100 \%$ similarity with $Y$. enterocolitica (accession number: KF758579.1, CP009846.1, MF152686.1).

After PCR to identify the virulence genes ail, yada, virf, ystA, and ystB, it was possible to verify that the six samples positive for $Y$. enterocolitica were positive only for the inv gene.

\section{Discussion}

Yersinia enterocolitica was not isolated in any of the milk samples using the three selective media. 
However, in all samples the exuberant isolation of colonies of mucoid characteristics was observed, including on the selective Yersinia agar. It was verified, therefore, that many different bacteria presented growth, even with the use of selective media and with the accomplishment of procedures prior to the incubation that aim to reduce microbial load.

Among the milk samples evaluated, Shigella sonnei, a Gram negative enterobacterium, was isolated, although it was not the subject of the present study. It was an important finding because it is pathogenic and is commonly related to infections caused by the ingestion of contaminated food and water. The presence of this bacterium isolated from tank milk reveals a potential risk when consuming raw or uninspected milk (MATTOCK; BLOCKER, 2017).

Other authors have also obtained similar results, suggesting that it is not possible to isolate $Y$. enterocolitica when associated with the exuberant growth of other enterobacteria in the Yersinia selective medium, such as Klebsiella, Enterobacter, Citrobacter, Serratia, Pseudomonas, and Aeromonas, indicating possible bacterial competition and, therefore, interference in the results (BORRALHO et al, 1999; PADILHA et al., 2001; PINTO et al., 2006). These methodological difficulties in isolation may be due to $Y$. enterocolitica having reduced microbial load in the samples, due to the microbiota of the milk being rich in diverse microorganisms, thus hindering the processes of isolation and identification (DARWISH et al., 2015).

In order to evaluate if $Y$. enterocolitca was actually experiencing difficulties in the competitiveness of the rich microbiota of raw milk, a test was performed to evaluate this characteristic. Even diffused in very high concentrations, Yersinia enterocolitica couldn't be re-isolated due to the predominant isolation of mucoid colonies of other contaminating bacteria. The competitiveness test showed the difficulty of isolating Yersinia enterocolitica in highly contaminated foods such as raw milk.

The PCR performed from the suggestive colonies was also negative, confirming the results of the microbiological isolation, that is, that the $Y$. enterocolitica couldn't be isolated in the media used. However, the PCR performed directly from the extraction of DNA from the raw bed detected $Y$. enterocolitica in six samples (5.9\% of the samples), later confirmed by sequencing. Several other studies that have not been successful in the microbiological isolation of $Y$. enterocolitica due to the exuberant isolation of other bacteria, as in the present study, were able to detect Yersinia DNA when they were submitted to conventional PCR (TEODORO et al., 2006; HANIFIAN; KHANI, 2012; DARWISH et al., 2015). This result indicates that molecular methods should be incorporated into routine diagnoses when the presence of $Y$. enterocolitica is suspected, especially when the material to be isolated is heavily contaminated, such as raw milk.

The classical virulence genes found in pathogenic biotypes, such as ail, yada, ystA, and virf, were not found in any of the positive samples studied. In contrast, the inv gene was found in all positive samples. The inv gene is responsible for the adhesion of $Y$. enterocolitica to the epithelial cells of the ileum and colon. However, studies have shown that inv gene sequences may be present in both invasive and non-invasive $Y$. enterocolitica isolates, the latter type being non-functional (DRUMMOND et al., 2012). Because none of the virulence genes investigated has been found, it is not possible to state that the detected Yersinia enterocolitic DNAs belonged to virulent strains, that is, strains capable of causing yersiniosis in humans.

During the visits to the dairy farms for milk collection, several risk factors were observed close to the bulk tanks, such as the presence of animals of several species, some with respiratory symptoms such as nasal discharge, and others presenting diarrhea, dirty environments, presence of sewage, 
rubbish, and rubbish dumps. It is important to report that in two properties, pigs were found, and a suckling pig was observed licking milk debris from the outlet of the bulk tank in one of the farm, emphasizing that the milk sample of this bulk tank was $Y$. enterocolitica-positive by PCR.

Rodents, dogs, cats, birds, and specially pigs are known reservoir animals of $Y$. enterocolitica. In swine, the 4/0:3 bioserogroup has been frequently isolated, and this variety is most commonly associated with diseases in humans (TRABULSI; ALTERTHUM, 2015). In addition, studies have shown that strains found in swine and infected humans show the same genotypic profiles and have all of the virulence genes, reinforcing the notion that that swine species are an important reservoir and potentially a source of infection of the pathogen for other animals and humans (RUSAK et al., 2014).

In a study carried out in Rio Grande do Sul, the prevalence of $Y$. enterocolitica in raw milk was reported as $9.37 \%$ by means of molecular analysis, a little higher than found in this study. Additionally, the pathogen was identified in the water used in the milking parlor and in the hands of manipulators, emphasizing the risk of contamination during milk production due to lack of good milking practices (TAVARES et al., 2017).

In Brazil, $Y$. enterocolitica has already been identified in pasteurized milk. The contamination may have occurred due to failures during the pasteurization procedure or due to recontamination after the heat treatment, by cross-contamination in the beneficiation line (FALCÃO et al., 2006). The milk industry should make efforts to avoid this type of contamination by adopting strict control of good manufacturing practices and considering the risk of receiving already contaminated milk. It is also necessary to require good milking practices from milk suppliers, in addition to periodically educating them through training (RUEGG, 2003).

\section{Conclusions}

Methodological difficulties were found in the microbiological isolation due to the high contamination levels of the milk; however, results of the molecular analysis revealed the presence of Yersinia enterocolitica in raw milk, indicating the effectiveness of PCR in diagnosis of this bacterium from highly contaminated samples. The only gene found was inv, which despite having an important role in invasion, may also be present in non-pathogenic strains. Although virulence genes known to be present in potentially pathogenic strains of Yersinia enterocolitica have not been identified, the presence of this pathogen in milk from expansion tanks, identified through PCR and confirmed by genetic sequencing, suggests that Yersinia enterocolitica may be a risk to public health, especially if milk and its derivatives are consumed without heat treatment. There is need for improvement in milking practices, as well as increasing awareness of the population regarding the risks of consuming milk and its raw and clandestine derivatives.

\section{Acknowledgements}

To São Paulo Research Foundation - FAPESP for aiding the research process 2016/15908-6 and Master's degree grant, process 2016/03582-9; to Professor Juliana Falcão, from the University of Pharmaceutical Sciences of Ribeirão Preto, USP, for kindly ceding a sample of Yersinia enterocolitica DNA; to FIOCRUZ for the Yersinia reference strains of the serological group 1B, 2, 3, 4, and 5 (FIOCRUZ Reference CLIST: 3438, 3439, 3440, 3442 , and 3443), from the collection of cultures of the Department of Bacteriology of IOC/FIOCRUZ of Rio de Janeiro, RJ).

\section{References}

ARCURI, E. F.; SILVA, P. D. L.; BRITO, M. P. V. P.; BRITO, J. R. F.; LARNGE, C. C.; MAGALHÃES, M. M. A. Contagem, isolamento e caracterização de bactérias psicrotróficas contaminantes de leite cru refrigerado. 
Ciência Rural, Santa Maria, v. 38, n. 8, p. 2250-2255, 2008.

BALAKRISHNA, K.; RADHIKA, M.; MURALI, H. S. Specific identification of pathogenic Yersinia enterocolitica by monoclonal antibodies generated against recombinant attachment invasion locus (rAil) protein. World Journal of Microbiology and Biotechnology, Berlin, v. 28, n. 2, p. 533-539, 2012.

BIER, O. Bacteriologia e imunologia. 17. ed. São Paulo: Melhoramentos, 1984. 1968 p.

BORRALHO, E.; ALBUQUERQUE, M. C.; CARDOSO, M. Pesquisa de Yersinia enterocolitica em linguiças frescas de porco em Porto Alegre, RS. Ciência Rural, Santa Maria, v. 29, n.4, p. 727-729, 1999.

BRASIL. Ministério da Agricultura Pecuária e Abastecimento. Decreto $\mathrm{n}^{\circ}$ 9. 013, de 29 de março de 2017. Regulamenta a Lei $n^{\circ} 1.283$, de 18 de dezembro de 1950, e a Lei $n^{\circ} 7.889$, de 23 de novembro de 1989, que dispõem sobre a inspeção industrial e sanitária de produtos de origem animal. Diário Oficial [da] União, Brasília, 2017. Seção 1, p. 3. Disponível em: <http:// www.agricultura.gov.br>. Acesso em: 2 aug. 2017.

DALLAL, M. M. S.; TABARRAIE, A.; MOEZARDALAN, K. Comparison of four methods for isolation of Yersinia enterocolitica from raw and pasteurized milk from northern Iran. International Journal of Food Microbiology, Amsterdam, v. 94, n. 1, p. 87-91, 2004.

DARWISH, S. F.; ASFOUR, H. A. E.; ALLAM, H. A. Incidence of Yersinia enterocolitica and Yersinia pseudotuberculosis in raw milk samples of different animal species using conventional and molecular methods. Alexandria Journal of Veterinary Sciences, Alexandria, v. 44, n. 1 p. 174-185, 2015.

DEAN, A. G.; SULLIVAN, K. M.; SOE, M. M. OpenEpi: open source epidemiologic statistics for public health. Update 2015/05/04. (Programa Estatístico online). Available at: $<\mathrm{http}: / /$ www.OpenEpi.com>. Accessed at: 16 oct. 2015.

DRUMMOND, N.; MURPHY, B. P.; RINGWOOD, T.; PRENTICE, M. B.; BUCKLEY, J. F.; FANNING, S. Yersinia enterocolitica: a brief review of the issues relating to the zoonotic pathogen, public health challenges, and the pork production chain. Foodborne Pathogens and Disease, Larchmont, v. 9, n. 3, p. 174-189, 2012.

FALCÃO, J. P.; FALCÃO, D. P.; DIAS, A. M. G.; CORREA, E. F. Microbiological quality of ice used to refrigerate foods. Food Microbiology, London, v. 19, n. 4, p. 269-276, 2002.
FALCÃO, J. P.; FALCÃO, D. P.; SILVA, A. P.; MALASPINA, A. C.; BROCCHI, M. Molecular typing and virulence markers of Yersinia enterocolitica, strains, from human, animal and food, origins isolated between 1968 and 2000 in Brazil. Journal of Medical Microbiology, Edinburgh, v. 55, n. 11, p. 1539-1548, 2006.

HANIFIAN, S.; KHANI, S. Prevalence of virulent Yersinia enterocolitica in buck raw milk and retail cheese in northern-west of Iran. International Journal of Food Microbiology, Amsterdam, v. 155, n. 2, p. 89-92, 2012.

KAYLEGIAN, K. E.; MOAG, R.; GALTON, D. M.; BOOR, K. J. Raw milk consumption beliefs and practices among New York State dairy producers. Food Protection Trends, Des Moines, v. 2, n. 3, p. 184-191, 2008.

MARTINS, K. B.; MARTINS-FACCIOLI, P. Y.; RIBOLI, D. F. M.; PEREIRA, C. V.; FERNANDES, S.; OLIVEIRA, A. A.; DANTAS, A.; ZAFALON, L. F.; CUNHA, M. L. R. S. Clonal profile, virulence and resistance of Staphylococcus aureus isolated from sheep milk. Brazilian Journal of Microbiology, São Paulo, v. 46, n. 2, p. 533-543, 2015.

MATTOCK, E.; BLOCKER, A. J. How do the virulence factors of shigella work together to cause disease? Frontiers in cellular and infection microbiology, Bristol v. 64, n. 7, p. 1-24, 2017.

PADILHA, M. R. F.; FERNANDES, Z. F.; LEAL, A. T. C. A.; LEAL, N. C.; ALMEIDA, A. M. P. Pesquisa de bactérias patogênicas em leite pasteurizado tipo C comercializado na cidade do Recife, Pernambuco Brasil. Revista da Sociedade Brasileira de Medicina Tropical, Rio de Janeiro, v. 34, n. 2, p. 67-171, 2001.

PINTO, P. S. A.; TEODORO, V. A. M.; VANETTI, M. C. D.; BELIVALACQUA, P. D.; MORAES, M. P.; PINTO, M. S. Aplicação de técnica de PCR na detecção de Yersinia enterocolitica em suínos abatidos sem inspeção. Arquivo Brasileiro de Medicina Veterinária e Zootecnia, Belo Horizonte, v. 58, n. 1, p. 9-14, 2006.

RASMUSSEN, H. N.; OLSEN, J. E.; RASMUSSEN, O. F. RAPD analysis of Yersinia enterocolitica. Letters in Applied Microbiology, Oxford, v. 19, n. 19, p. 359-362, 1994.

RUEGG, P. L. Practical food safety interventions for dairy production. Journal of Dairy Science, Lancaster, v. 86, p. E1-E9, 2003. Supplement Special.

RUSAK, L. A.; REIS, F. C. M. F.; BARBOSA, A. V.; SANTOS, A. F. M.; PAIXÃO, R.; HOLER, E.; VALLIM, D. C.; ASENSI, M. D. Phenotypic and genotypic analysis of bio-serotypes of Yersinia enterocolitica from various 
sources in Brazil. Journal of Infection in Developing Countries, Rio de Janeiro, v. 8, n. 12, p. 1533-1540, 2014.

L, M.; SALONEN, M.; PULKKINEN, H.; HUUSKONEN, M.; HELLSTROM, S.; REVEZ, J.; HANNINEN, M. L.; FREDRIKSSON-AHOMAA, M.; LINDSTROM, M. Pathogenic bacteria in finnish bulk tank milk. Foodborne Pathogens and Disease, Larchmont, v. 10, n. 2 p. 99-106, 2013.

SILVA JUNIOR, E. A. Manual de controle sanitário em serviços de alimentação. 7. ed. São Paulo: Varela, 2014.

SOLTAN-DALLAL, M. M.; TABARRAIE, A.; MOEZARDALAN, K. Comparison of four methods for isolation of Yersinia enterocolitica from raw and pasteurized milk from northern Iran. International Journal of Food Microbiology, Amsterdam, v. 94, n. 1, p. 87-91, 2004.

STENKOVA, A. M.; ISAEVA, M. P.; RASSKAZOV, V. A. Development of a multiplex PCR procedure for detection of Yersinia genus with identification of pathogenic species (Y. pestis, Y. pseudotuberculosis, and Y. enterocolitica). Molecular Genetics, Microbiology and Virology, New York, v. 23, n. 3, p. 119-125, 2008.

TAVARES, A. B.; SOUZA, A. I. A.; DULAC, C. F.; MOREIRA, L. M.; DOMINGUEZ, L.; GONZALEZ, H. L.; CERESER, N. D.; TIMM, C. D. Fontes de contaminação de Yersinia enterocolitica durante a produção de leite. Arquivo Brasileiro de Medicina Veterinária e Zootecnia, Belo Horizonte, v. 69, n. 2, p. 483-490, 2017.

TEODORO, V. A. M.; PINTO, P. S. A.; VANETTI, M. C. D.; BEVILACQUA, M. P.; PINTO, M. S. Aplicação da técnica de PCR na detecção da Yersinia enterocolitica em suínos abatidos sem inspeção. Arquivo Brasileiro de Medicina Veterinária e Zootecnia, Belo Horizonte, v. 58, n. 1, p. 9-14, 2006.

THOERNER, P.; BIN KINGOMBE, C. I.; BOGLISTUBER, K.; BISSIG-CHOISAT, B.; WASSENAAR, T. M.; FREY, J.; JEMMI, T. PCR detection of virulence gene distribution. Applied and Environmental Microbiology, Washington, v. 69, n. 3, p. 1810-1816, 2003.

TRABULSI, L. R.; ALTERTHUM, F. Microbiologia. 6. ed. São Paulo: Atheneu, 2015.

VIDON, D.; DELMAS, C. L. Incidence of Yersinia enterocolitica in raw milk in Eastern France. Applied and Environmental Microbiology, Washington, v. 41, n. 2, p. 355-359, 1981.

WAUTERS, G.; KANDOLO, K.; JANSSENS, M. Revised biogrouping scheme of Yersinia enterocolitica. Contributions to Microbiology and Immunology, Basel, v. 9, n. 4, p. 14-21, 1987. 